
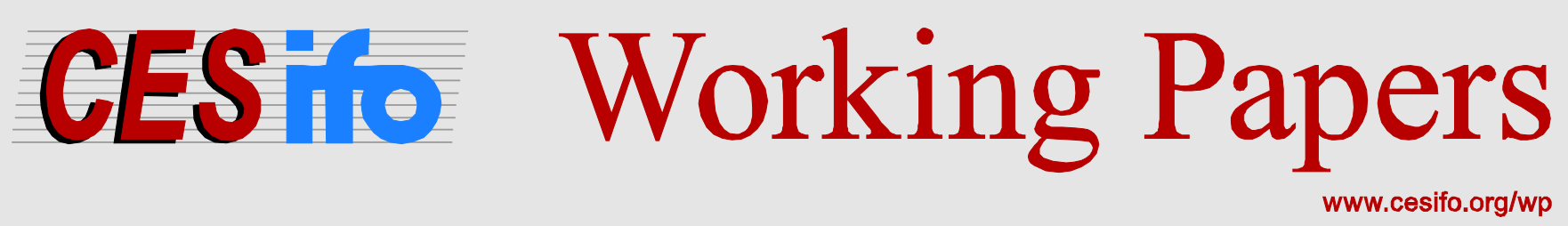

\title{
Who Has Terror Angst? Perceptions of the Effects of Terror on the World Economy
}

\author{
Dorine Boumans \\ Johanna Garnitz \\ Günther Schulze
}

CESIFO WORKING PAPER No. 6049

Category 2: Public ChOICE

August 2016

An electronic version of the paper may be downloaded

- from the SSRN website:

- from the RePEc website:

- from the CESifo website:

www.SSRN.com

www.RePEc.org

www.CESifo-group.org/wp 


\title{
Who Has Terror Angst? Perceptions of the Effects of Terror on the World Economy
}

\begin{abstract}
We examine sources of biased terror perceptions. In particular, we investigate how international experts of the IFO World Economic Survey assess the effect of terror on the world economy and the economy of their own country. The results show that respondents from terror stricken countries have more favorable views on the effect of terror on the word economy (but not on their own countries). Male respondents and those from democratic and richer countries are likewise more optimistic.
\end{abstract}

JEL-Codes: D740, D840, F010.

Keywords: terror, terror angst, terror perceptions, consequences of terror.

Dorine Boumans

Ifo Institute - Leibniz Institute for

Economic Research at the University of Munich

Poschingerstrasse 5

Germany-81679 Munich

boumans@ifo.de
Johanna Garnitz

Ifo Institute - Leibniz Institute for

Economic Research

at the University of Munich

Poschingerstrasse 5

Germany - 81679 Munich

garnitz@ifo.de

\author{
Günther Schulze* \\ University of Freiburg \\ Department of Economics \\ Platz der Alten Synagoge 1 \\ Germany- 79085 Freiburg \\ guenther.schulze@vwl.uni-freiburg.de
}

*corresponding author

August 5, 2016

This paper was written while Günther Schulze was visiting IFO Institute in February 2016. GS is grateful for the outstanding hospitality of the IFO Institute. We are indebted to Niklas Potrafke for helpful comments. The usual disclaimer applies. 


\section{Introduction}

A central goal of terrorists is to create fear and insecurity; a second one is to destabilize the economy and society. Creating fear and perceptions of heightened risk is essential for achieving all other goals of terrorist organizations, notably hurting the economy or mobilizing potential followers. Terror affects the economy directly through the loss of lives, human capital, and the destruction of physical infrastructure; yet these effects are typically small in comparison to the indirect effects that occur by actions not taken. A prime example is reduced FDI inflows into countries exposed to terror. Abadie and Gardeazabal (2008) show that changes in terrorism may lead to large reallocations of capital across countries - a one standard deviation increase is associated with a drop in the net FDI position of around 5 percent of GDP. This finding has been corroborated by a number of case studies and cross-country analyses. Enders and Sandler (1996) show a marked decline of FDI in Greece (-14\%) and Spain (-12 \%) as a consequence of terror; Bandyopadhyay et al. (2013) demonstrate the sizeable and significantly negative effect of terror on FDI for a panel of 78 countries for the period 1984-2008, Filer and Stanišić (2016) support this finding in their panel analysis of 160 countries 1980-2008. A second example is the steep decline in tourist inflows after terror has hit a country (Enders et al. 1992, Neumayer 2004, Llorca-Vivero 2008). Neumayer (2004) shows that a one standard deviation increase in terror reduces tourism inflows by 7 percent in the short run and 15 percent in the long run. Llorca-Vivero (2008) updates the analysis and finds that a one standard deviation increase leads to a decline in tourist numbers of around 10 to 16 percent, depending on the specification used. Other prime examples of economic activities not undertaken are reduced overall investment, reduced consumption expenditures (Llussá and Tavares 2011) and declining trade (Nitsch and Schumacher 2004). Moreover, governments may reduce productive activities as resources are diverted to security outlets (Brück 2005).

This decline in economic activity is brought about by a change in perceptions in the aftermath of terror events. Output growth is expected to decline, investments are deemed more risky and travels no longer safe, and as a result, economic activity is scaled back - expectations become in part self-fulfilling. The formation of expectation thus is central for the effect of terror. ${ }^{1}$ Yet, how are perceptions formed on the risk of economic setbacks through terror? More importantly, to what extent are these perceptions biased? This is inherently difficult to assess, because there is no 'objective' measure on the true effect of terror on the economy. ${ }^{2}$

We are the first to analyze these perception biases due to a unique feature of our data. The IFO World Economic Survey (WES) 2016, unlike all other surveys, asked for perceived terror effects on the national economy and on the world economy. While the perceived terror effects on the national economy should

\footnotetext{
${ }^{1}$ Cf. Naor (2015) for a theoretical model.

${ }^{2}$ This is in contrast to corruption perceptions which can, at least in principle, be compared to the true level of corruption (cf. Olken 2009 for an example). If respondents from countries with higher terror levels expect terror to have a larger effect on their economies than respondents from countries with low terror intensity, it implies that expectations are non-contradictory, but it does not imply unbiased or rational expectations.
} 
be affected by characteristics of the respondent's country such as the number of terror incidents as a measure of terror intensity and economic development and the level of democracy as measure for the resilience of a country, the perceived terror effects on the world economy should not. The effect of terror on the global economy is independent of the location of the respondent and thus unbiased perceptions should be independent of the characteristics of the respondents' countries. This feature allows us to measure perception biases on the effect of terror, an issue that despite its importance has not yet been analyzed. Indeed, we find that perceptions on the effect of terror on the world economy are strongly influenced by country characteristics in a non-trivial way.

Our paper contributes to the scant literature on the determinants of fear of terrorism, but it differs in significant aspects. Previous contributions have been based on experimental evidence or surveys of the general population and have referred to the risk of terrorism in general (Brück and Müller 2010, Drakos and Müller 2014, Lerner et al. 2003, Sjöberg 2005) or of being killed by terrorists (Rosenboim et al. 2012, Viscusi 2009). In contrast, we focus on terror effects on the economy as perceived by carefully selected experts. It is not only a much more focused issue; experts are also better informed and thus less prone to perception biases and emotional manipulation (Fischhoff et al. 2005). Moreover, experts serve as opinion leaders and thus influence investors' perceptions and thereby impact on investment.

Existing studies analyzed respondents from specific countries such as Germany, the US, Israel or Sweden, or selected EU countries, and thus referred to the specific situation in that country; our survey is global covering respondents from 100 countries. By allowing to contrast the perceptions of terror effects on the national economy with those on the world economy we are able, for the first time, to analyze perception biases in assessing the economic effects of terrorism.

The paper proceeds as follows. Section 2 presents the data, Section 3 reports the results. Section 4 contains a number of robustness checks, Section 5 concludes.

\section{Data and Empirical approach}

\subsection{Dependent variable}

The World Economic Survey (WES), compiled by the Ifo Institute since 1981, aims at providing a timely and accurate picture of the current economic situation, as well as economic trends in over 100 key advanced, emerging or developing economies by polling more than 1,000 economic experts. ${ }^{3}$ In selecting experts the emphasis is placed on their professional competence in economic matters and inside knowledge of their countries. In addition to the assessment of macroeconomic variables, every quarter a one-off special question is asked about a relevant political or economic issue around the world. In

\footnotetext{
${ }^{3}$ https://www.cesifo-group.de/ifoHome/publications/journals/CESifo-World-Economic-Survey.html, Garnitz et al. (2016). The survey has been proven to predict business cycles quite well, cf. Kudymowa et al. (2013). Cf. Potrafke and Reischmann (2016) for an analysis of the WES on a possible exit of Greece from the Eurozone.
} 
January 2016 the following special question was asked: "How do you assess the effects of terrorism, or the potential fear of attacks, on economic sentiment for the world economy and your country respectively?". Possible answers were "absent", "low", "moderate", and "high".

In total 1,085 experts from 120 countries responded to the survey, which was fielded from $4^{\text {th }}$ to $27^{\text {th }}$ January 2016; 968 experts from 119 countries answered the special question. We focus on the perceived effect of terror on the world economy because this should be the same on average for all respondents irrespective of their home countries; we report the perceived effect on their own country for reasons of comparison. As less than three percent answered that an effect of terror on the world economy was absent, we merged the answers "absent" and "low" into one category. Response frequencies are given in Figure 1.

Figure 1: Perceptions on the effect of terror on national and world economy

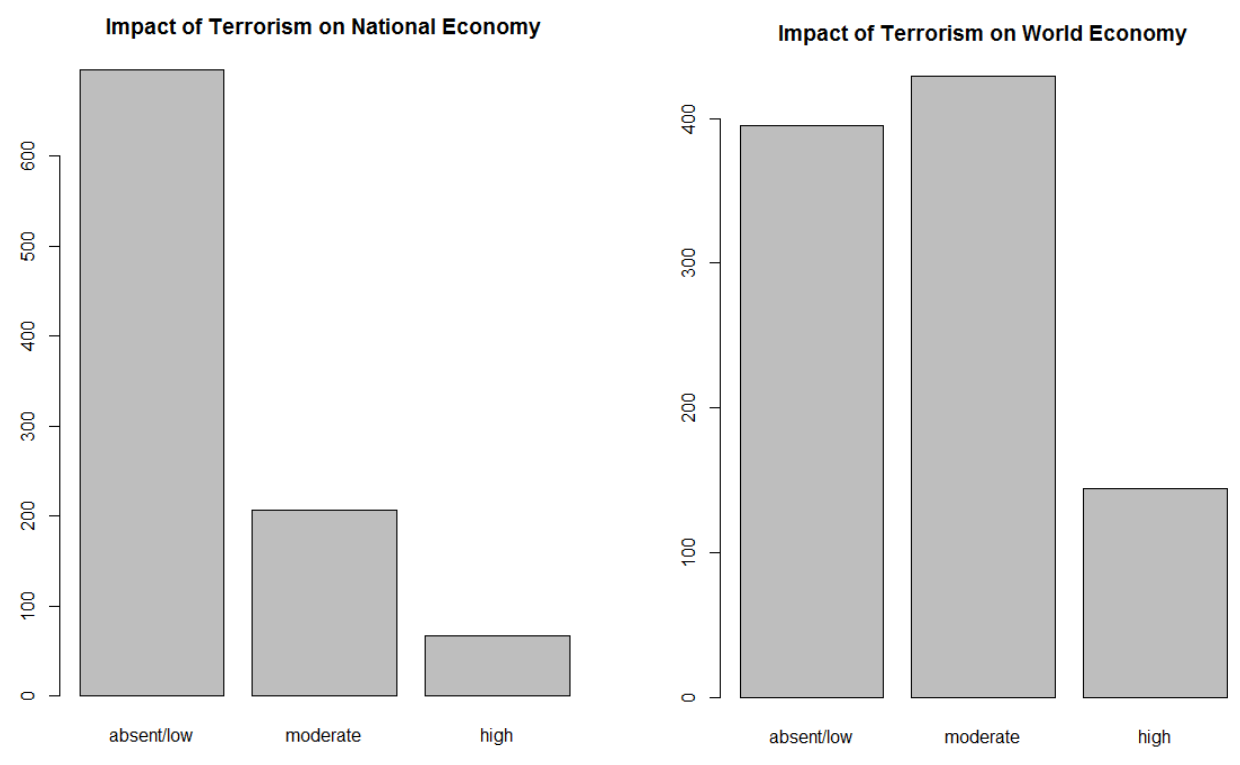

\subsection{Control variables}

\subsubsection{Individual characteristics}

We control for gender, age, educational background, and level of education, as these variables have been shown to affect terror risk perceptions (Brück and Müller 2010, Lerner et al. 2003, Sjöberg 2005, Viscusi 2009). We include a dummy "Female" that is one if the respondent is a woman, zero otherwise. To allow for a possible nonlinear relationship between age and perceptions on terror effects we experimented with a set of age dummies. In the end we included dummies for people aged 55 to 66 years and above 65 years since only these turned out significantly. The respondents' fields of study comprised economics $(54 \%)$, business $(17 \%)$, law $(3 \%)$, other social sciences $(4 \%)$, professional or applied sciences (7\%), humanities (3\%), and natural and other sciences (13\%). The only significant difference we 
found was between individuals with a business degree and the others. Therefore we include a dummy "education in business". As practically all respondents have at least a college or master degree, we distinguish only PhDs, which 44 percent of all respondents have. Moreover, we control for the organizations the experts are affiliated with. Respondents work in industry associations and chambers of commerce $(9.6 \%)$, central banks (3.7\%), banks and other financial institutions (12.3\%), companies and non-financial industries (26.0\%), national ministries and agencies (5.5\%), embassies and consulates (4.2\%), international organizations (2.6\%), universities (31.2\%), and other institutions. Descriptive statistics, including all data sources, are given in Table A1 in the appendix.

\subsubsection{Country characteristics}

Terror intensity: We use data from the Global Terrorism Database (GTD), which is provided by the National Consortium for the Study of Terrorism and Responses to Terrorism (START 2015). GTD, defines terrorism as "the threatened or actual use of illegal force and violence by a non-state actor to attain a political, economic, religious, or social goal through fear, coercion, or intimidation" (LaFree and Dugan, 2007, p. 184). GTD is currently the most comprehensive and most widely used data base of terrorism and includes domestic and transnational terrorism. It reports each incident by country including the number of wounded and killed (along with a number of other details of the attack).

We use the sum of terror incidents (in logs) in the country of residence as our measures of terror intensity as this is the measure most used in the literature. Alternatively we could use terror fatalities by country as terror measure. A priori it is unclear which measure of terror intensity affects perceptions more. The number of incidents is probably more closely related to number of terror reports in the media than to the overall number of terror fatalities as most terror incidents will be reported in the media; more deadly attacks might be more present in the media, ${ }^{4}$ but not in proportion to their fatalities more. Therefore the number of incidents should better capture the presence of terror in the media. Media presence in turn should be reflected in experts' terror perceptions. Yet, the overall death toll may portray the severity of terror better which should likewise be reflected in experts' opinions. In the end it is an empirical issue which measure explains perceptions better, if at all. We thus use terror fatalities as alternative measure of terror exposure in the robustness checks.

Resilience of an economy is proxied by the level of democracy, measured by the POLITY IV score, and the level of economic development as measured by both the log of GDP per capita and the urbanization rate since more developed and more democratic societies are less affected by any given level of terror (Blomberg et al. 2004, Sandler and Enders 2008, Tavares 2004). The POLITY score ranges from -10 indicating maximum autocracy to +10 (maximum democracy). We include the number of tourists and the degree of openness (exports plus imports as a share of GDP) because tourist-dependent and trade

\footnotetext{
${ }^{4}$ Jetter (2014) shows that the New York Times reports suicide attacks more often than other attacks. Suicide attacks tend to be more deadly than 'normal' attacks.
} 
intensive economies may be more vulnerable to terror as terror may disrupt these activities (LlorcaVivero 2008, Neumayer 2004, Nitsch and Schumacher 2004, Egger and Gassebner 2015). Lastly we control for countries with a majority-Muslim and majority Christian population, which may capture differences in religion, culture, and Weltanschauung, among other things.

Data refer to 2014; in the few cases in which 2014 data were not available, we used the latest available data. As our dependent variable is categorical we use ordered logit estimators. We estimated the model with and without Huber-White robust standard errors; as the results were only marginally different we report the uncorrected standard errors.

\section{Results}

Table 1 reports the baseline results in odds ratios. Individual characteristics have similar effects on the perceived terror effects at home (column 1) and worldwide (column 2). Most importantly, women are significantly more pessimistic than men are, i.e. they are more than twice as likely to perceive the effects as "moderate" than as "absent/low" or as "high" than as "moderate". This corroborates evidence derived from samples of the population at large (Lerner et al. 2003, Sjöberg 2005) for the specific group of highly educated experts. Individuals with a business degree are significantly more pessimistic regarding the effect of terror on the world economy. ${ }^{5}$ Individuals with a PhD are more optimistic concerning the effects of terror at home, but not worldwide. Lastly, older people are more likely to perceive terror as detrimental to the economy; a finding that is also in line with previous studies (Sjöberg 2005, Brück and Müller 2010). The effect is significant at usual levels for the 55 to 65 year old individuals for the domestic economy and for people over 65 years for the world economy.

Table 1: Baseline Results

\begin{tabular}{lcc}
\hline & $(1)$ & $(2)$ \\
VARIABLES & & \\
& terror effect on country & terror effect on world \\
\hline \multirow{2}{*}{ Female } & $2.389 * * *$ & $2.879 * * *$ \\
& $(4.060)$ & $(5.619)$ \\
Education in Business & 0.969 & $1.447^{*}$ \\
& $(-0.118)$ & $(1.727)$ \\
$55-65$ yrs old & $1.920^{* * *}$ & 1.328 \\
66 yrs and older & $(2.983)$ & $(1.525)$ \\
& 1.425 & $1.630^{* *}$ \\
PhD & $(1.248)$ & $(2.065)$ \\
& $0.655^{* *}$ & 0.911 \\
$\log ($ incidents) & $(-2.100)$ & $(-0.577)$ \\
& $1.292^{* * *}$ & $\mathbf{0 . 8 8 6 * *}$
\end{tabular}

\footnotetext{
${ }^{5}$ All other subjects are in sign and significance very similar to economists (the reference group). We also included respondents' affiliations, none of which had a significant effect (results not reported).
} 


\begin{tabular}{lcc} 
& $\mathbf{( 5 . 3 3 3 )}$ & $\mathbf{( - 2 . 9 5 3 )}$ \\
log(GDP per capita) & $0.702^{* * *}$ & $0.697^{* * *}$ \\
& $(-2.813)$ & $(-3.675)$ \\
Democracy & $0.949^{* *}$ & $0.962^{*}$ \\
& $(-2.387)$ & $(-1.903)$ \\
Openness & $1.007^{* * *}$ & 0.999 \\
& $(3.351)$ & $(-0.535)$ \\
Urbanization rate & $1.013^{*}$ & 0.999 \\
& $(1.689)$ & $(-0.211)$ \\
Number of tourists & $1.022^{* * *}$ & 0.999 \\
& $(5.056)$ & $(-0.253)$ \\
Majority of Christians & 1.505 & 1.263 \\
& $(1.452)$ & $(1.101)$ \\
Majority of Muslims & $4.920^{* * *}$ & 1.337 \\
Affiliation controls & $(5.099)$ & $(1.050)$ \\
& yes & yes \\
Constant cut1 & & \\
& 0.119 & $0.00149^{* * *}$ \\
Constant cut2 & $(-1.281)$ & $(-4.882)$ \\
& 0.796 & $0.0149^{* * *}$ \\
Observations & $(-0.137)$ & $(-3.180)$ \\
AIC & & 926 \\
BIC & 927 & 1802.297 \\
\hline
\end{tabular}

Notes: Ordered logit, endogenous variable: effect on terror is "absent or low", "moderate", "high", results are in odds ratios, $z$-statistics in parentheses, $* * * p<0.01,{ }^{* *} p<0.05,{ }^{*} p<0.1$

Characteristics of the respondents' countries affect perceptions on the effect of terror on their home economies as expected: respondents from countries with higher terror levels are more likely to perceive terror as detrimental to the domestic economy. Respondents from richer and more democratic countries are more optimistic; this too makes sense, as these countries are more resilient to any given level of terror (which we control for). Economies with more tourists and more trade are perceived as more vulnerable to terror as terror disrupts these international flows and thus affects GDP negatively (see above). Lastly, respondents from majority Muslim countries have significantly more pessimistic expectations, even after controlling for the level of terror. These results seem to suggest that the interviewed experts assess the effects of terror realistically.

However, results for the perceived terror effects on the world economy contradict this notion. Logically, the effect of terror on the world economy is unrelated to the characteristics of a specific country, and thus unbiased perceptions should not be influenced by characteristics of the respondents' origins. Yet they are. Respondents from countries with high levels of terror are significantly less likely to regard terror having a moderate or high effect on the world economy than individuals from less affected 
countries. In addition, respondents from more democratic and richer countries are less likely to attribute medium or large effects of terror on the world economy. All other variables are insignificant; especially religious composition, which exerts a very pronounced effect on the perceived effects on the national economy, has no significant impact for the perceived impact of terror on the world economy.

\section{Robustness checks}

\subsection{Alternative terror measure}

We first analyze whether our results remain robust if we use terror fatalities instead of terror incidents as a measure of terror intensity. Results are reported in Table 2 . They are very similar, the only notable difference is that the effect of terror fatalities on perceptions on the world economy is still negative, but no longer significant at the usual levels - it is significant at the 12 percent level. This difference may not be surprising: terror attacks typically make it into the headlines and therefore the number of incidents reflects the media presence of terror; the number of terror fatalities may be less memorized by respondents. Yet, as we will see below, our results are corroborated for fatalities as measure of terror exposure when we allow for a more flexible empirical setup (Section 4.2).

Table 2: Fatalities as alternative terror measure

\begin{tabular}{lcc}
\hline & $(3)$ & $(4)$ \\
VARIABLES & terror effect on country & terror effect on world \\
\hline \multirow{3}{*}{ female } & $2.419^{* * *}$ & $2.881^{* * *}$ \\
& $(4.118)$ & $(5.632)$ \\
Education in Business & 0.964 & $1.459^{*}$ \\
& $(-0.137)$ & $(1.766)$ \\
$55-65$ yrs old & $1.879^{* * *}$ & 1.312 \\
& $(2.875)$ & $(1.461)$ \\
66 yrs and older & 1.411 & $1.643^{* *}$ \\
& $(1.211)$ & $(2.100)$ \\
PhD & $0.620^{* *}$ & 0.926 \\
& $(-2.353)$ & $(-0.478)$ \\
log(fatalities) & $\mathbf{1 . 3 0 1 * * *}$ & $\mathbf{0 . 9 4 2}$ \\
& $(5.906)$ & $(-1.546)$ \\
log(GDP per capita) & $0.726^{* *}$ & $0.716^{* * *}$ \\
& $(-2.540)$ & $(-3.406)$ \\
Democracy & 0.972 & $0.955^{* *}$ \\
& $(-1.295)$ & $(-2.257)$ \\
Openness & $1.007^{* * *}$ & 1.000 \\
& $(3.564)$ & $(-0.190)$ \\
Urbanization rate & $1.014^{*}$ & 0.998
\end{tabular}




\begin{tabular}{lcc} 
& $(1.863)$ & $(-0.288)$ \\
Number of tourists & $1.025^{* * *}$ & 0.997 \\
& $(5.714)$ & $(-0.906)$ \\
Majority of Christians & 1.391 & 1.349 \\
& $(1.177)$ & $(1.422)$ \\
Majority of Muslims & $4.816^{* * *}$ & 1.281 \\
& $(5.003)$ & $(0.897)$ \\
Affiliation controls & yes & yes \\
Constant cut1 & 0.224 & $0.00270 * * *$ \\
& $(-0.889)$ & $(-4.429)$ \\
Constant cut2 & 1.519 & $0.0267^{* * *}$ \\
& $(0.248)$ & $(-2.733)$ \\
Observations & 927 & 926 \\
AIC & 1282.982 & 1808.69 \\
BIC & 1394.117 & 1919.8 \\
\hline
\end{tabular}

Notes: see Table 1, ${ }^{a}$ significant at the 12 percent level.

\subsection{Non-linear effects of terror}

The previous specifications constrained terror incidents or fatalities to have a linear effect on perceptions. This might not capture adequately the underlying mechanism of forming perceptions on the effect of terror - it rules out nonlinearities and threshold effects. To allow for nonlinearities or threshold effects in the influence of domestic terror levels on perceptions for the national and the world economy we define four dummies: (1) "no terror", (2) "terror incidents/fatalities between 1 and 10", (3) "between 11 and 100", and (4) "more than 100 incidents/fatalities". "No terror" is the omitted category. Table 3 reports the results. Models (1) to (4) correspond to those in Tables 1 and 2, the only difference is the different terror variables.

Table 3: Semi-parametric approach
(1)
(2)
(3)
(4)

\begin{tabular}{|c|c|c|c|}
\hline \multirow{2}{*}{$\begin{array}{l}\text { VARIABLES } \\
\text { more than } 100 \text { incidents }\end{array}$} & terror effect on country & \multicolumn{2}{|c|}{ terror effect on world } \\
\hline & $5.576 * * *$ & $0.485^{* * *}$ & \\
\hline & $(5.719)$ & $(-2.761)$ & \\
\hline \multirow[t]{2}{*}{ incidents between 11 and 100} & $1.721^{* *}$ & 0.945 & \\
\hline & (1.971) & $(-0.269)$ & \\
\hline \multirow[t]{2}{*}{ terror incidents between 1 and 10} & $1.874^{* *}$ & $1.467 * *$ & \\
\hline & $(2.500)$ & (2.060) & \\
\hline \multirow[t]{2}{*}{ more than 100 fatalities } & $6.070^{* * *}$ & & $0.589 * *$ \\
\hline & (5.994) & & $(-1.989)$ \\
\hline \multirow[t]{2}{*}{ fatalities between 11 and 100} & $1.837^{* *}$ & & 0.797 \\
\hline & (2.194) & & $(-0.902)$ \\
\hline
\end{tabular}


Notes: see Table 1; control variables as in Tables 1 and 2.

The perceived effect of terror on the domestic economy increases monotonously in the number of fatalities and almost monotonously in the number of incidents. ${ }^{6}$ This is sensible given that more domestic terror should affect the domestic economy more severely (after controlling for different levels of resilience).

In contrast, we find strong nonlinearities for the perceived terror effects on the world economy. The picture is similar for incidents and fatalities, even if significance levels differ. Respondents from terrorstricken countries (more than 100 incidents/fatalities) are significantly more optimistic regarding the effect of terror on the world economy than any other group. Odds ratios are 0.5 for incidents and 0.6 for fatalities, which is very sizeable. Individuals from countries with medium terror levels (11-100 incidents/fatalities) respond no different than individuals from countries with no terror (the reference group). The most gloomy perceptions are by people with very low, but positive terror levels, at least if we measure terror by the number of incidents.

\subsection{Further robustness checks}

We carried out a number of further robustness checks. We used gross national income per capita and the human development index in lieu of GDP per capita, we used incidents and fatalities in levels rather than in logs and we replaced the two dummies for religion by a variable for the share of Muslims in the country. These changes did not affect our results in any significant way. Results are available upon request.

\section{Concluding Remarks}

We analyzed the perceptions of international experts regarding the effect of terror on their respective home countries' economies as well as on the world economy. Experts' perceptions are affected by individual characteristics such as gender, age and education: women and older people have more pessimistic, PhDs more optimistic perceptions, which corroborates earlier findings for this highly selective group of international economic experts.

For the perceived effects of terror on the domestic economy country characteristics have the expected influence: respondents from countries with high terror levels are more likely to be pessimistic, larger

\footnotetext{
${ }^{6}$ Coefficients for terror level dummies 1-10 incidents and 11-100 incidents are not statistically significantly different, cf. Table 3, model 1.
} 
resilience of the home country - i.e. more democratic, more developed countries - makes experts' perceptions more likely to be favorable.

Yet, also the perceived effect of terror on the world economy is influenced by the characteristics of respondents' home countries, which clearly demonstrates that perceptions on terror effects are biased. As the state of the world economy is independent of the location of the observer, differences in perceptions across individuals should be random. Yet they are systematic: Respondents from more democratic and more developed countries have more optimistic perceptions. Most surprisingly, however, more terror at home makes people more optimistic about how little terror affects the global economy (as opposed to their domestic economy). Allowing for non-linear effects of terror levels at home on perceptions for the global economy gives rise to an intricate picture: experts from terrorstricken countries with more than 100 incidents or fatalities p.a. are very sizably and significantly more optimistic than experts from countries with less or no terror. Most pessimistic are respondents from countries with low $(\leq 10)$ but positive terror incidents.

These perception biases may indicate a learning process regarding the economic effects of terror. People exposed to high levels of terror at home may realize that the economic effect of terror may not be as bad as their peers in more peaceful countries think they are, especially given that worldwide terror levels are lower than at home. Individuals experiencing low but positive levels of terror at home may perceive terror as real threat (in contrast to respondents from countries without terror), but they may overestimate their economic effects. Similar perception biases exists for GDP per capita and democracy: As respondents live in more resilient countries they transfer their positive experiences to the world as a whole and are thus less pessimistic.

Our finding may have important policy implications. The change in expectations is responsible for the lion's share of the economic effects of terror - economic activities such as FDI, domestic investment, private consumption are scaled back for the bleak expectations that terror creates - not so much the direct destruction of productive capacities. Because these expectations for the world economy are most unfavorable in countries that are exposed to little terror, enhanced counterterrorist activities may be called for also in those countries, which from a purely operational point of view would need less of these activities, because they may improve perceptions just as foreign investors' perceptions can be improved by counterterrorism activities (Lee 2016). Moreover, especially people from countries with little (but some) terror need to learn more about the very limited effects of terror on the economy from people with experiences of higher terror levels. This might lead them to adjust their expectations. Eventually this information transmission may be a very cheap and effective way to alter perceptions and ultimately deny terrorists the effects they are striving for. 


\section{Appendix}

Table A1: Descriptive statistics

\begin{tabular}{|c|c|c|c|c|c|c|}
\hline Variable & Obs & Mean & Std. Dev. & Min & Max & Source \\
\hline $\begin{array}{l}\text { Perceived effect of terror } \\
\text { on world economy }\end{array}$ & 968 & .741 & .700 & 0 & 2 & (1) \\
\hline $\begin{array}{l}\text { Perceived effect of terror } \\
\text { on domestic economy }\end{array}$ & 969 & .351 & .605 & 0 & 2 & (1) \\
\hline Female & 971 & .138 & .345 & 0 & 1 & $(2)$ \\
\hline Education in Business & 971 & .103 & .304 & 0 & 1 & (2) \\
\hline $55-65$ yrs old & 971 & .158 & .365 & 0 & 1 & $(2)$ \\
\hline 66 yrs and older & 971 & .087 & .281 & 0 & 1 & $(2)$ \\
\hline PhD & 971 & .264 & .441 & 0 & 1 & $(2)$ \\
\hline Log(incidents) & 971 & 1.876 & 1.871 & 0 & 7.672 & (3) \\
\hline Log(fatalities) & 971 & 1.244 & 1.988 & 0 & 8.959 & (3) \\
\hline Log(GDP per capita) & 963 & 16.464 & 1.260 & 12.726 & 18.599 & (4) \\
\hline Democracy & 961 & 7.739 & 3.917 & -10 & 10 & (5) \\
\hline $\begin{array}{l}\text { Openness } \\
\text { exports + imports, in \% of GDP }\end{array}$ & 948 & 85.617 & 53.367 & 19.119 & 439.200 & (6) \\
\hline Urbanization rate (ppt) & 971 & 69.318 & 18.211 & 8.55 & 100 & (6) \\
\hline $\begin{array}{l}\text { Number of tourists } \\
\text { (million arrivals) }\end{array}$ & 970 & 18.267 & 21.826 & .019 & 83.767 & (6) \\
\hline Majority of Christians & 971 & .749 & .434 & 0 & 1 & (6) \\
\hline Majority of Muslims & 971 & .103 & .304 & 0 & 1 & (7) \\
\hline
\end{tabular}

\section{Sources:}

(1) IFO World Economic Survey 2016, cf. Garnitz et al. (2016).

(2) IFO World Economic Survey 2014.

(3) National Consortium for the Study of Terrorism and Responses to Terrorism (START), Global Terrorism Database. Retrieved from http://www.start.umd.edu/gtd (20 March 2015).

(4) International Monetary Fund, World Economic Outlook Database October 2015.

(5) Polity IV Project (2014), Political Regime Characteristics and Transitions, 1800-2014. Retrieved from http://www.systemicpeace.org/inscrdata.html (10 March 2016).

(6) World Bank (2016) World Development Indicators, World Bank Open Data. Retrieved from http://data.worldbank.org (02 May 2016).

(7) Maoz, Zeev and Errol A. Henderson (2013), The World Religion Dataset, 1945-2010: Logic, Estimates, and Trends. International Interactions, 39: 265-291. 


\section{References}

Abadie, A. and J. Gardeazabal (2008), Terrorism and the World Economy, European Economic Review 52:1-27.

Bandyopadhyay, S., T. Sandler, and J. Younas (2014), "Foreign Direct Investment, Aid, and Terrorism" Oxford Economic Papers 66(1): 25-50.

Blomberg, S., Hess, D., Orphanides, A. (2004), The macroeconomic consequences of terrorism. Journal of Monetary Economics 51, 1007-1032.

Brück, Tilman (2005), An economic analysis of security policies, Defence and Peace Economics, 16(5): 375-389.

Brück, Tilmann and Cathérine Müller (2010), Comparing the Determinants of Concern about Terrorism and Crime, Global Crime, 11(1): 1-15.

Drakos, Konstantinos and Catherine Müller (2014), On the Determinants of Terrorism Risk Concern in Europe, Defence and Peace Economics, 25(3): 291-310.

Drakos, Konstantinos and Cathérine Müller (2011), Terrorism risk concern in Europe, Economics Letters, 112: 195-197.

Egger, Peter and Martin Gassebner (2015), International terrorism as a trade impediment? Oxford Economic Papers, 67 (1): 42-62.

Enders, WalterTodd Sandler and G.F. Parise (1992), An Econometric Analysis of the Impact of Terrorism on Tourism, Kyklos, 45(4): 531-554.

Enders, Walter and Todd Sandler (1996), Terrorism and foreign direct investment in Spain and Greece. Kyklos, 49, 331-352.

Filer, Randall K. and Dragana Stanišić (2016), The Effect of Terrorist Incidents on Capital Flows, Review of Development Economics, 20(2), 502-513.

Fischhoff, Baruch, Roxana Gonzalez, Jennifer Lerner and Deborah Small (2005), Emotions, Risk Perceptions, and Precautionary Behavior Under the Threat of Terror Attacks, Journal of Experimental Psychology: Applied, 11(2): 124-139.

Garnitz, Johanna, Gernot Nerb, Klaus Wohlrabe and Dorine Boumans (2016), CESifo World Economic Survey February 2016, CESifo World Economic Survey 15 (1), 01-25, Ifo Institute, Munich, 2016, https://www.cesifo-group.de/ifoHome/publications/docbase/details.html?docld=19189944

Jetter, Michael (2014) Terrorism and the Media, Forschungsinstitut zur Zukunft der Arbeit (Institute for the Study of Labor) discussion paper 8497, available at http://citeseerx.ist.psu.edu/viewdoc/download?doi=10.1.1.670.8236\&rep=rep1\&type=pdf

Kudymowa, Evgenia, Johanna Plenk and Klaus Wohlrabe (2013), Ifo World Economic Survey and the Business Cycle in Selected Countries, CESifo Forum 4/2013, pp 51-57.

LaFree, Gary and Laura Dugan (2007) Introducing the global terrorism database, Terrorism and Political Violence, 19 (2): 181-204.

Lee, Chia-Yi (2016) Terrorism, Counterterrorism Aid, and Foreign Direct Investment, Foreign Policy Analysis, published online 19. May 2016, DOI: http://dx.doi.org/10.1111/fpa.12087. 
Lerner, Jennifer, Roxana Gonzalez, Deborah Small and Baruch Fischhoff (2003), Effects of Fear and Anger on Perceived Risks of Terrorism: A National Field Experiment, Psychological Science, 14(2): 144150.

Llussá, F. and J. Tavares (2011), Which terror at which cost? On the economic consequences of terrorist attacks, Economics Letters 110: 52-55.

Llorca-Vivero, R. (2008), Terrorism and International Tourism: New Evidence, Defence and Peace Economics, 19(2): 169-188.

Naor, Ziv (2015), Why a small probability of terror generates a large macroeconomic impact, Defence and Peace Economics, 26:6, 583-599.

Neumayer, Eric (2004), The impact of political violence on tourism: A dynamic cross-national estimation, Journal of Conflict Resolution, 48(2): 259-281.

Nitsch, Volker and Dieter Schumacher (2004), Terrorism and international trade: An empirical investigation, European Journal of Political Economy, 20(2): 423-433.

Potrafke, Niklas and Markus Reischmann (2016), How to Handle the Crisis in Greece? Empirical Evidence Based on a Survey of Economics Experts, CESifo Working Paper No. 5860, available at https://www.cesifo-group.de/ifoHome/publications/workingpapers/CESifoWP/CESifoWPdetails?wp num=5860\&CESifoWP.search=

Rosenboim, Mosi, Uri Benzion, Shosh Shahrabani and Tal Shavit (2012), Emotions, Risk Perceptions, and Precautionary Behavior Under the Threat of Terror Attacks: A Field Study Among Israeli College Students, Journal of Behavioral Decision Making, 25: 248-256.

Sandler, Todd and Walter Enders (2008), Economic Consequences of Terrorism in Developed and Developing Countries, in Keefer, Philip and Loayza, Norman (eds.), Terrorism, Development and Political Openness, Cambridge: Cambridge University Press, pp. 17-47.

Sjöberg, Lennart (2005), The Perceived Risk of Terrorism, Risk Management, 7(1): 43-61.

START (2015) National Consortium for the Study of Terrorism and Responses to Terrorism (START), Global Terrorism Database. Retrieved from http://www.start.umd.edu/gtd (20 March 2015).

Tavares, José (2004), The open society assesses its enemies: shocks, disasters and terrorist attacks. Journal of Monetary Economics 51, 1039-1070.

Viscusi, W. Kip (2009), Valuing Risks of Death from Terrorism and Natural Disasters, Journal of Risk and Uncertainty, 38: 191-213. 